A R C H I V E

O F

M E C H A N I C A L

E N G I N E E R I N G

\begin{tabular}{llr}
\hline VOL. LXIII & 2016 & Number 1
\end{tabular}

10.1515/meceng-2016-0001

Key words: kinematic analysis, tram powertrain, coupling system

MICHAE MANIOWSKI *, TOMASZ CZAUDERNA *

\title{
SPATIAL KINEMATIC ANALYSIS OF DOUBLE 4-LINK COUPLER USED IN LOW-FLOOR TRAM POWERTRAINS
}

\begin{abstract}
The paper presents kinematic characteristics of the double 4-link coupler system, used in actual powertrain of low-floor trams (NGT6-Kr). The spatial kinematic model of the couplings was formulated assuming ideal joints and rigid members. The constraints equations of the mechanism were solved iteratively and differentiated to obtain the Jacobian matrix. The mobility and singularity analysis of the coupler mechanism was performed on the basis of the Jacobian matrix.

Kinematic characteristics of the single and double coupler system were analyzed for gross angular and linear axle displacements (misalignments), taking the advantage of the fully nonlinear model. The coupling system was evaluated based on criteria describing homokinetics, balancing and clearance demands, and angular displacements in the joints. These criteria were determined for different design parameters like: coupler proportions, platform shift and angle, middle shaft length.
\end{abstract}

\section{Introduction}

\subsection{Coupler systems used in rail vehicles}

In this paper a double 4-link (push-rod) couplers system, used to transfer torques in actual powertrain of low-floor tram, is analyzed with respect to its kinematic properties by using simulation model of the spatial mechanism with ideal kinematic joints.

There are different coupler systems used to transfer drive and brake torques between electric motors and wheel sets in powertrain systems of tram vehicles $[7,13]$. The considered coupler system must allow free displacement of the wheel set according to its primary suspension functions, transferring the torque in a smooth manner.

* Cracow University of Technology, Mechanical Department, Al. Jana Pawła II 37b, 31-864 Kraków,Poland; E-mails: mmaniowski@pk.edu.pl; tczauder@mpk.krakow.pl 
Main components of a powertrain system used in the low floor tram NGT6-Kr, which are used in Cracow city transport [9], are presented in Fig. 1. Starting from the rail vehicle boogie (1), torque from the electric motor (2) is modified by (3) reduction gear, next transferred to axial hollow(4) and linked by two couplers (5) and intermediate hollow (6) with axle of the wheel set (7). Main advantage of this configuration is significant reduction of rolling unsprung masses, by full decoupling of heavy motor from the wheel sets. Additionally, classic solution of the boogies in comparison with e.g. portal type powertrains, gives lower cost and higher reliability [7].

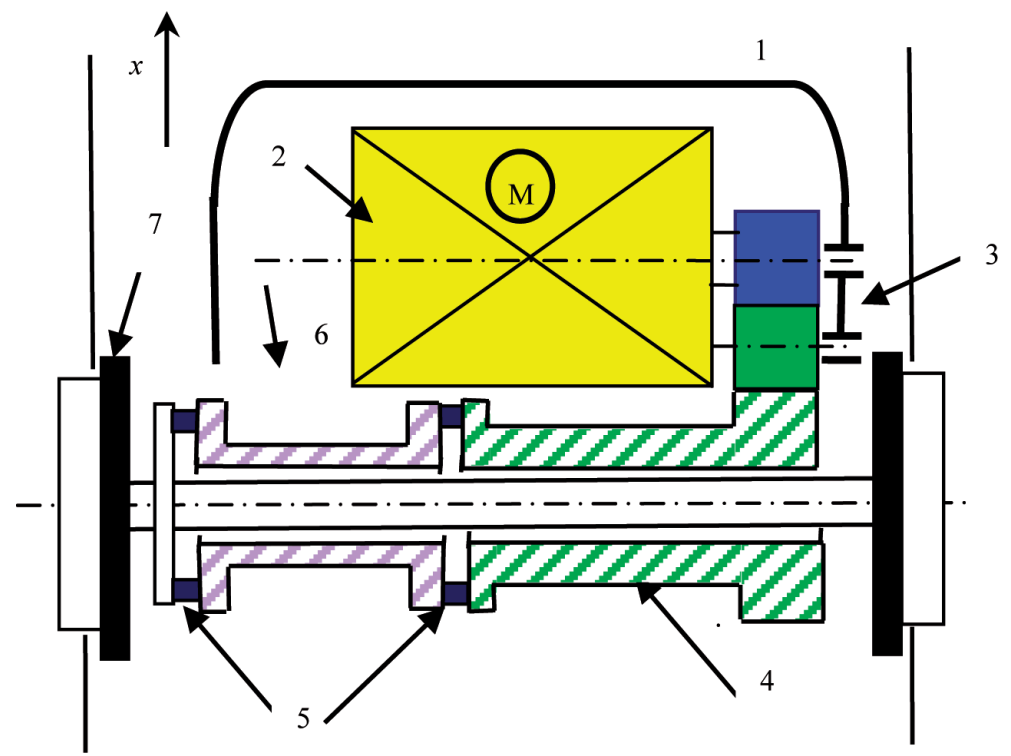

Fig. 1. Typical configuration of power train in tram vehicles: 1 - boogie with: (2) electric motor, (3) reduction gear; (4) hollow; 5 - four-link couplers (FLENDER); 6 - intermediate hollow; 7 axle with rail wheels

The photo of the assembled double 4-link coupler system is presented in Fig. 2a. It is composed of a rail wheels axle (Fig. 2b) and a reduction gear and hollow (Fig. 2c), where both parts include platforms with (flexible) joints of the coupler links.

There are many resources describing this kind of multi-link coupler mechanism as parallel platform mechanisms [3, 10, 11, 12]. Their application in rail vehicles is described, regarding design aspects, in [7]. In majority of scientific papers this kind of coupler is simplified and analyzed as a planar model $[5,14]$, that gives useful results for small displacements of the coupler axles.

This paper deals with a double 4-link couplers system modeled as spatial mechanism with nonlinear kinematic constraints, with special focus on: 
a)

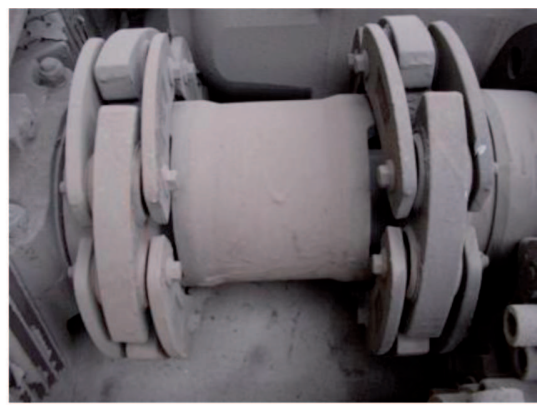

b)

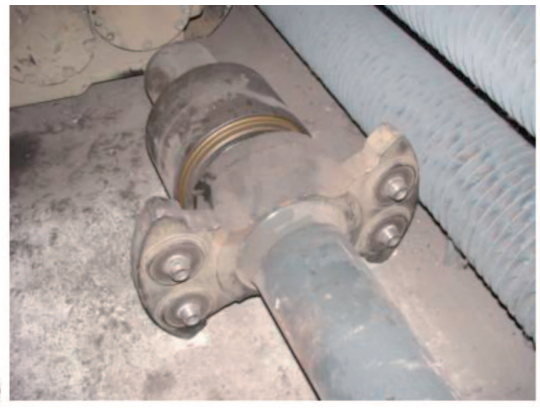

c)

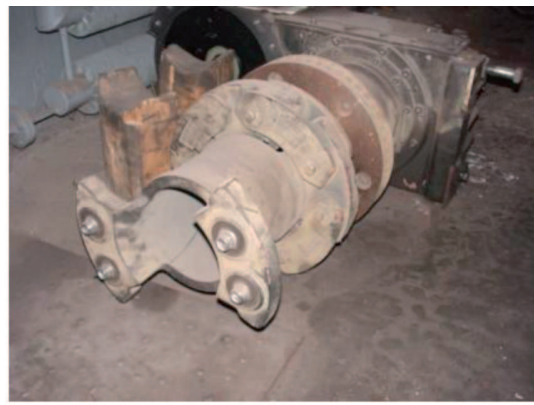

Fig. 2. Views of assembled (a) and disassembled parts of 4-link coupler, (b) axle of rail wheels, (c) hollow with reduction gear

- mobility and singularity analysis of the entire mechanism with kinematic constraints;

- gross angular and linear axle displacements are considered, what requires a full nonlinear model,

- the coupler system is evaluated based on criteria describing homokinetics, balancing and clearance demands, and displacements of the links bushings.

\subsection{Design objectives for the coupler systems}

The following design objectives are defined in the paper as important features for evaluation of different coupler systems [1,2]:

a) high transferred torque strength (the higher, the better);

b) huge acceptable displacements (angular and linear misalignments) of shafts (the bigger, the better);

c) balancing (static and dynamic balancing should be possible);

d) trajectory changes of the movable platform center, which require greater clearance between axle and hollows;

e) small changes in kinematic ratios for angular velocities (homokinetic condition);

f) mass (the less, the better); 
g) gross dimensions (the less, the better);

h) small relative displacements in bushings of the joints, which simplify selection of the elastomeric bushing parameters;

i) durability (fatigue strength requirements);

j) vibration isolation (minimization of powertrain vibrations).

In this paper the criteria (b), (c) and (d) are studied using formulated kinematic models of 4-link coupler. The remaining criteria can be analyzed with using a dynamic model [11] or model based on finite elements method (FEM).

\subsection{Goals and scope of the paper}

Main goal is a kinematic analysis of a single and double 4-link coupler using a spatial multi-body model, including rigid bodies and ideal joints, formulated in Matlab software [6]. The defined above problem is not covered in a known literature.

Obtained kinematic characteristics can be used for:

- better understanding of the mechanism features;

- propositions of base-line design improvements;

- formulation of elastokinematic or dynamic model in the future phase of studies.

\section{Kinematic model of 4-link coupler}

\subsection{Assumptions}

Main assumptions for the kinematic analysis of a single coupler, presented in Fig. 3, are the following:

- platforms (yokes) A, B and C are rigid, with the same geometry, symmetrically installed on perpendicular shafts;

- input shaft-a is constrained by R-joint with respect to the tram boogie (Fig. 1);

- combined platforms with links are described by two parameters (Fig. $3)$, i.e.: radius $(R)$ of inscribed circle and length $(l)$ of the links;

- platform radius equals unity $(R=1)$ for better conditioning of the problem;

- each link, of the same length, is rigid and ended with Spherical (S) joints;

- local degrees of freedom of the SS-links are neglected;

- collisions and displacement constraints of the platforms and links are not analyzed. 

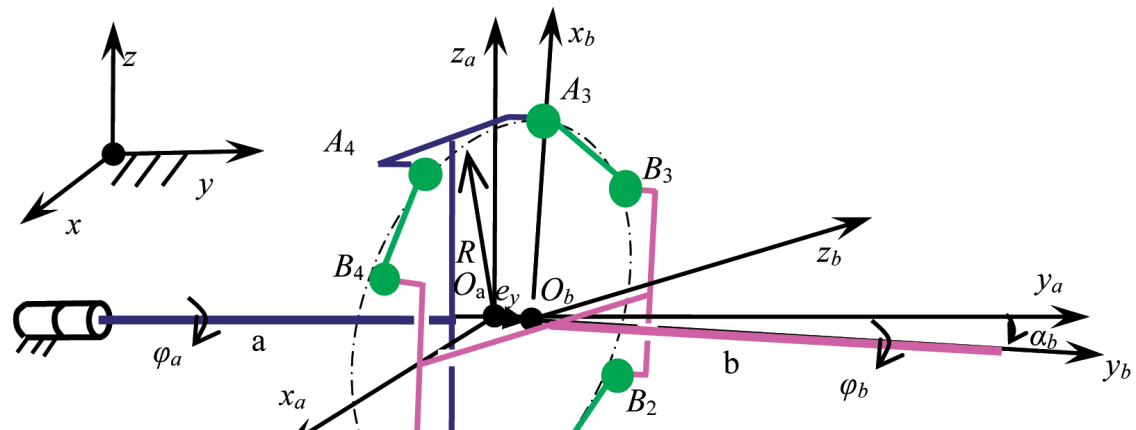

a)

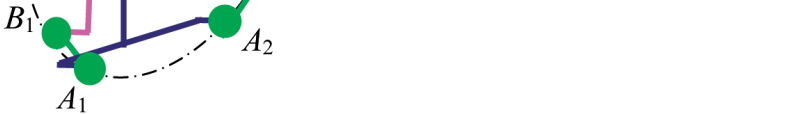

b)

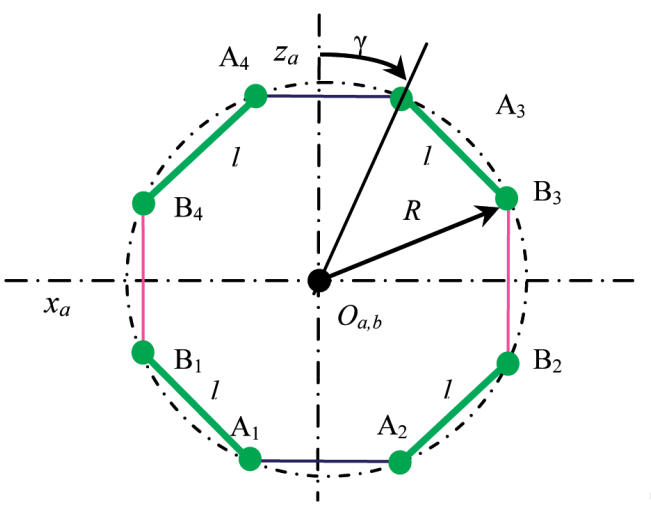

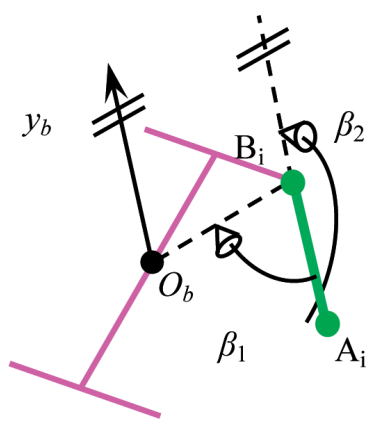

c)

Fig. 3. a) Kinematic scheme of a single coupler with 4 SS-links in a general pose; b) Geometry of both platforms of 4-link coupler in initial (coplanar) pose; c) Definition of angles between link and platform

Relationship between dimensions of the planar platform (Fig. 3) is described as follows:

$$
\left(\frac{l}{R}\right)^{2}=2(1-\sin (2 \gamma)) .
$$

In case of a single 4-link coupler there are 2 rigid bodies, Tab. 1. For given 3 active constraints $\left(\varphi_{a}, \alpha_{b x}\right.$ - rotation of platform-B relative to axis $x_{b}, \alpha_{b z}$ - rotation of platform-B relative to axis $\left.z_{b}\right)$, there are 4 coordinates $\left(\varphi_{b}, x_{b}\right.$, $y_{b}, z_{b}$ ) to be determined, under 4 constraints equations (from 4 SS-links).

In the case of a double 4-link coupler (Fig. 4), there are 3 rigid bodies, Tab. 1. For given 5 active constraints $\left(\varphi_{a}, \alpha_{c x}, \alpha_{c z}, x_{c}, z_{c}\right)$, there are 8 coordinates $\left(\varphi_{b}, y_{c}, x_{b}, y_{b}, z_{b}, \varphi_{b}, \alpha_{b x}, \alpha_{b z}\right)$ to be determined, under 8 constraints equations (from 4 SS-links). 
Parameters for kinematic analysis of a single and double 4-link coupler

\begin{tabular}{|c|c|c|}
\hline Parameters & Single 4 -link coupler & Double 4-link coupler \\
\hline $\begin{array}{l}\text { Number of rigid } \\
\text { bodies }\end{array}$ & $\begin{array}{l}\text { 1) input shaft-a with platform-A; } \\
\text { 2) output shaft-b with platform-B; }\end{array}$ & $\begin{array}{l}\text { 1) input shaft-a with platform-A; } \\
\text { 2) intermittent shaft-b with } \\
\text { platforms-AB and -BC; } \\
\text { 3) output shaft-c with platform } C \text {; }\end{array}$ \\
\hline $\begin{array}{l}\text { Motion con- } \\
\text { ditions (active } \\
\text { constraints) }\end{array}$ & $\begin{array}{l}\text { 1) } \varphi_{a}-\text { input shaft rotation angle; } \\
\text { 2) } \alpha_{b x}-\text { output shaft inclination as } \\
\text { rotation relative to } x \text {; } \\
\text { 3) } \alpha_{b z}-\text { output shaft inclination as } \\
\text { rotation relative to } z ;\end{array}$ & $\begin{array}{l}\text { 1) } \varphi_{a} \text { (see left) } \\
\text { 2) } \alpha_{c x}-\text { output shaft inclination as } \\
\text { rotation relative to } x \text {; } \\
\text { 3) } \alpha_{c z}-\text { output shaft inclination as } \\
\text { rotation relative to } z \text {; } \\
\text { 4) } x_{c}-x \text {-component of shaft-c pos- } \\
\text { tion; } \\
\text { 5) } z_{c}-z \text {-component of shaft-c pos- } \\
\text { tion. }\end{array}$ \\
\hline $\begin{array}{l}\text { Number of con- } \\
\text { straints eqs }\end{array}$ & 4 (from 4 SS-links) & 8 (from 8 SS-links) \\
\hline $\begin{array}{l}\text { Variables to be } \\
\text { determined }\end{array}$ & $\begin{array}{l}\varphi_{b}-\text { output shaft-b rotation angle; } \\
x_{b}, y_{b}, z_{b}-\text { position coordinates of } \\
\text { platform-B; }\end{array}$ & $\begin{array}{l}\varphi_{c}-\text { output shaft-c rotation angle; } \\
y_{c}-y \text {-component of shaft-c postion; } \\
x_{b}, y_{b}, z_{b} \text { (see left); } \\
\varphi_{b}, \alpha_{b x}, \alpha_{b z}-\text { orientation angles of } \\
\text { platform-B; }\end{array}$ \\
\hline Design variables & $\begin{array}{l}\text { 1) } \gamma \text { (describes proportions of the } \\
\text { platforms, eq. 2); } \\
\text { 2) } e_{y}-\text { axial shift between } \\
\text { platforms-AB (this parameter re- } \\
\text { quires proper changes in length }(l) \\
\text { of the links). }\end{array}$ & $\begin{array}{l}\text { 1) } \gamma \text { (see left); } \\
\text { 2) } e_{y} \text { (see left); } \\
\text { 3) } l_{b} \text { length of the b-shaft; } \\
\text { 4) } \varphi_{b c} \text { angle }(0 \text { or } 90 \mathrm{deg}) \text { between } \\
\text { axes } z_{b a} \text { and } z_{b c} \text { on shaft-b. }\end{array}$ \\
\hline
\end{tabular}

\subsection{Kinematic constraint equations}

In order to find the coupler system poses for the given (above) assumptions and defined input data and active constraints, kinematic passive constraints must be described algebraically and solved iteratively [3].

Platform-A (Figs. 3, 4) with input shaft can make rotations described by $\varphi_{a}$ (the first active constraint) with respect to $y$-axis. Transformation of $A_{i}$ points, i.e. centers of S-joints, from platform-A reference system to the base reference system is the following:

$$
\boldsymbol{a}_{i}=\boldsymbol{R}^{a} \boldsymbol{a}_{i}^{a} ; \quad i=1,2 \ldots 4,
$$

where:

$\boldsymbol{a}_{i}^{a}$ - position vector of the point $A_{i}$ in reference system fixed to platform-A, $\boldsymbol{a}_{i}$ - position vector of the point $A_{i}$ in the base reference system, 


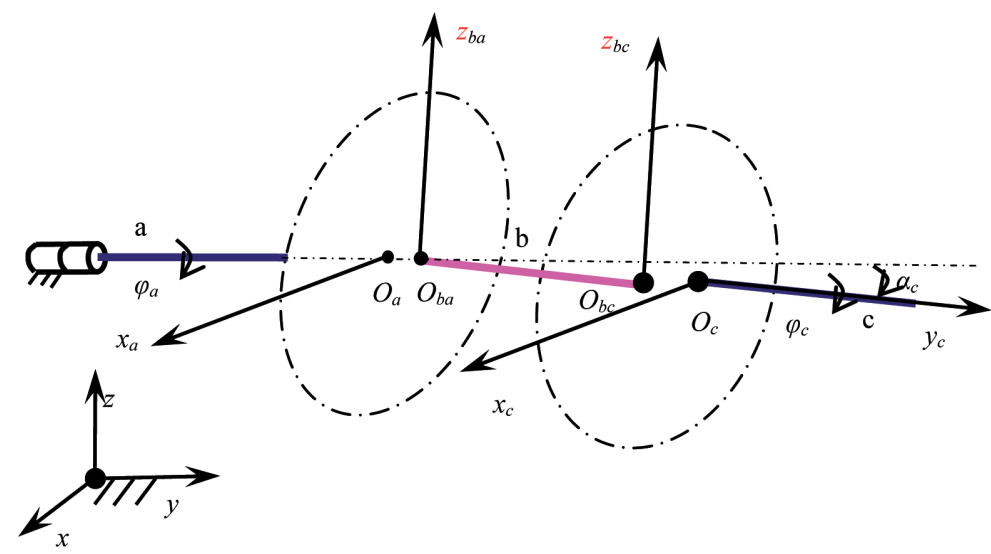

Fig. 4. Kinematic scheme of a double coupler with 4 SS-links in a general pose

$$
\boldsymbol{R}^{a}=\left[\begin{array}{ccc}
\cos \left(\varphi_{a}\right) & 0 & \sin \left(\varphi_{a}\right) \\
0 & 1 & 0 \\
-\sin \left(\varphi_{a}\right) & 0 & \cos \left(\varphi_{a}\right)
\end{array}\right]
$$

The poses of the platform-B (Figs. 3, 4) can be found by applying passive constraints, due to four SS-links, and active constraints describing limitations of output shaft displacements because of its installation with the rest of power train system (Fig. 1). The transformation of $B_{i}$ points, i.e. centers of $S$-joints on platform-B, from platform-B reference system to the base reference system is the following:

$$
\boldsymbol{b}_{i}=\boldsymbol{R}^{b} \boldsymbol{b}_{i}^{b}+\boldsymbol{o}^{b} ; \quad i=1,2 \ldots 4,
$$

where:

$\boldsymbol{b}_{i}^{b}-$ position vector of the point $B_{i}$ in reference system fixed to platform-B, $\boldsymbol{b}_{i}-$ position vector of the point $B_{i}$ in the base reference system,

$\boldsymbol{R}^{b}=f\left(\varphi_{b}, \alpha_{b z}, \alpha_{b x}\right)$, $\boldsymbol{o}^{b}=\left[x_{b} y_{b} z_{b}\right]^{T}+\boldsymbol{e}_{B A}$.

It is assumed that the output shaft can change its inclination, what is described by two following (misalignment) angles: (1) $\alpha_{b z}$ - rotation of platform-B relative to axis $z_{b}$, (2) $\alpha_{b x}$ - rotation of platform-B relative to axis $\mathrm{x}_{b}$, which are given as active constraints.

Passive constraints describing each SS-link, are expressed as constant distances between the corresponding points of two platforms, giving four, nonlinear algebraic equations:

$$
\boldsymbol{l}_{i}^{T} \boldsymbol{l}_{i}=l_{i}^{2} ; \quad i=1,2 \ldots 4 ;
$$

where:

$$
\boldsymbol{l}_{i}=\boldsymbol{b}_{i}-\boldsymbol{a}_{i} ; \quad i=1,2 \ldots 4,
$$


$l_{i}$ - denotes constant length $\left(l_{i}=\left\|\boldsymbol{l}_{i}\right\|\right)$ of $i$-th link.

The forward position problem of the considered single coupler mechanism (Fig. 3) is based on a solution to the constraints equations (4), which are solved iteratively by Gauss-Newton method [6].

In the case of the double coupler system (Fig. 4), the output shaft is connected with platform-C. Additionally, an intermittent shaft with two platforms (BA and BC) at its ends must be included in the mechanism. Platform-BA is connected with platform-A with four links, and platform-BC is connected with platform-C with successive four links.

In this case, transformation (3) takes the following form:

$$
\begin{array}{rlrl}
\boldsymbol{a}_{i} & =\boldsymbol{R}^{b} \boldsymbol{a}_{i}^{b}+\boldsymbol{o}^{b} ; & i=1,2 \ldots 4, \\
\boldsymbol{c}_{i}=\boldsymbol{R}^{b} \boldsymbol{c}_{i}^{b}+\boldsymbol{o}^{b} ; & i=1,2 \ldots 4,
\end{array}
$$

where:

$\boldsymbol{a}_{i}^{b}$ - position vector of the point $A_{i}$ in reference system fixed to platform-B,

$\boldsymbol{c}_{i}^{b}$ - position vector of the point $C_{i}$ in reference system fixed to platform-B,

$\boldsymbol{a}_{i}$ - position vector of the point $A_{i}$ in the base reference system,

$\boldsymbol{c}_{i}$ - position vector of the point $C_{i}$ in the base reference system.

Passive constraints for SS-links, have the same form (4), but count 8 equations, and concern link vector in the form:

$$
\begin{aligned}
\boldsymbol{l}_{i}=\boldsymbol{a}_{i}-\boldsymbol{a}_{i} ; & i=1,2 \ldots 4, \\
\boldsymbol{l}_{i}=\boldsymbol{c}_{i}-\boldsymbol{c}_{i} ; & i=1,2 \ldots 4,
\end{aligned}
$$

There is more mobility in the double coupler system than in the single one. Therefore, active constraints must be added to describe some components of output shaft-C position and orientation. It is assumed that the output shaft can have defined inclination (misalignment) angle and side position. This is described by two angles $\left(\alpha_{c z}, \alpha_{c x}\right)$ and two $(x$ and $z)$ components of its position.

\subsection{Mechanism mobility, singularities and free motions}

Mobility is the main structural parameter of a mechanism, defined as the number of independent coordinates needed to define the configuration of a kinematic chain [10]. It is well assumed that we deal with a mechanism if the mobility is at least one. There are various methods for mobility calculations of the closed loop mechanism [4]. Each method has its benefits and drawbacks. In this paper a rank of the mechanism constraints equations are used for mobility criterion. In order to apply this method, first the mechanism Jacobian matrix should be defined [10]. 
The mechanism Jacobian matrix depends on the mechanism configuration and can be derived by differentiating the motion constraint equations (4). Jacobian matrix $(\boldsymbol{J})$ represents transformation between rates $(\dot{\boldsymbol{w}})$ of the platform Cartesian coordinates ( 3 for position and 3 for orientation):

$$
\dot{\boldsymbol{w}}=\left[\dot{x} \dot{y} \dot{z} \dot{\beta}_{x} \dot{\beta}_{y} \dot{\beta}_{z}\right]^{T}
$$

and rates of the $n$ configuration coordinates $(\dot{\boldsymbol{q}})$ :

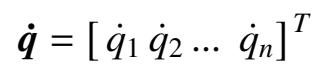

in the linear form:

$$
\dot{\boldsymbol{w}}=\boldsymbol{J}^{T} \dot{\boldsymbol{q}} .
$$

In the case of a single coupler (Fig. 3) with 4 SS-links, the configuration coordinates are chosen as:

$$
\boldsymbol{q}=\left[l_{1} l_{2} l_{3} l_{4}\right]^{T} .
$$

The coupler Jacobian matrix (10) can be written as:

$$
\boldsymbol{J}_{4 \times 6}=\left[\begin{array}{llll}
\hat{\boldsymbol{l}}_{1} & \hat{\boldsymbol{l}}_{2} & \ldots & \hat{\boldsymbol{l}}_{4}
\end{array}\right]^{T},
$$

where each column of the matrix means a unit spatial vector of $i$-th link [8], defines as:

$$
\hat{\boldsymbol{l}}_{i}=\left[\hat{\boldsymbol{l}}_{i}^{T}\left(\left(\boldsymbol{o}^{c}-\boldsymbol{b}_{i}\right) \times \hat{\boldsymbol{l}}_{i}\right)^{T}\right]^{T} .
$$

In the case of nonsingular configuration of the mechanism, the Jacobian matrix is full rank $(n)$. Any loss of the Jacobian matrix rank means singularity where the mechanism degrades its controllability. In the case of a parallel kinematic chain, the mechanism in singular configurations gains additional degrees of freedom.

It is useful to know how far the mechanism is from its singular configurations (when the Jacobian looses its rank). Conditioning number of the Jacobian matrix is frequently used for this purpose [4].

It is defined by:

$$
\chi(\boldsymbol{J})=\frac{\sigma_{\text {max }}}{\sigma_{\text {min }}}
$$

where $\sigma_{\max }$ and $\sigma_{\min }$ mean the max and min of the singular values of the matrix (14).

Approaching to singular position, this condition number tends to infinity. In ideal case, when the condition number equals unity, the mechanism has isotropic features, i.e. is described by the same kinematic ratios in each direction in space. 
In order to study a local free motions of the mechanism in singular configuration, the following feature of the Jacobian matrix (Eq. 14) can be utilized. In the case when the Jacobian loses its rank, an orthogonal complement of its null space gives a set of normalized admissible displacements [4]. These free motions describe changed behavior of the mechanism in singularity. In order to put more insight about the mechanism free motions, they are often transformed to screw motion parameters [8]. Screw parameters are defined by: screw axis, rotation angle about the screw axis and the screw pitch.

\section{Analysis of a single 4-link coupler}

\subsection{Simulations plan}

First, characteristics of a single 4-link coupler (Fig. 3) are studied by using the formulated kinematic model, implemented in Matlab software. The plan of simulations includes changes in the design variables (like: $\gamma$ - describing proportions of the platforms, $\boldsymbol{e}_{y}$ - vector $f$ axial shift between platforms, etc) and active constraints $\left(\varphi_{a}-\right.$ input shaft rotation angle; $\alpha_{b}-$ output shaft inclination angle) of the coupler, Tab. 2.1. It is assumed that that input axle can rotate the full angle.

Changing proportions of the mechanism, one can obtain the platforms described by different lengths of the links. In the case of $\gamma=0.11 \mathrm{rad}$, the platforms are more slim and links are longer than original $(\gamma=0.297 \mathrm{rad})$, and in the case of $\gamma=0.391 \mathrm{rad}$, the platforms are more wide and links are shorter.

\subsection{Single coupler mobility and free motions}

It is assumed that when both platforms of the single coupler are coplanar, the mechanism gains additional degree of freedom. In order to prove this numerically, the mechanism mobility and local free motions are analyzed based on the Jacobian matrix (Eq. 10) of the mechanism with $\gamma=0.297 \mathrm{rad}$ (original).

Graphical representation of simulation when the platform-B approaches with the following increments of $e_{y}$ to the (fixed) platform-A, is presented in Fig. 5. The determined admissible displacements of the platform-B with respect to A are expressed by the screw (S) axes, included in Tab. 2 for the three positions $\left(e_{y}=0,0.05,0.1[\mathrm{~m}]\right)$ of the platform.

The screw axes $\mathrm{S} 1$ and $\mathrm{S} 2$ describe two instantaneous rotations (screw pitch is close to zero) with respect to the perpendicular axes (along $x$ and $z$ axis of the base frame), which do not intersect, besides the platforms coplanar 

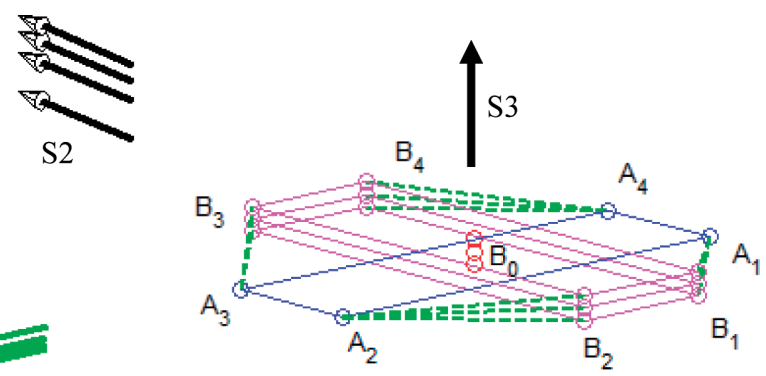

Fig. 5. Axes of free motions for platforms approaching a common plane

Table 2.

Screw parameters of free motions of the mechanism approaching singularity

\begin{tabular}{|c|c|c|c|c|c|c|}
\hline $\begin{array}{l}\text { position } \\
e_{.}[\mathrm{m}]\end{array}$ & \multicolumn{5}{|c|}{ Screw parameters of free motions } & \multirow{2}{*}{$\begin{array}{c}\text { Condition } \\
\text { number } \\
\chi(\boldsymbol{J})\end{array}$} \\
\hline & Screw & $\begin{array}{l}\text { Axis unit } \\
\text { vector }\end{array}$ & $\begin{array}{l}\text { Axis position } \\
\text { vector }[\mathrm{m}]\end{array}$ & $\begin{array}{c}\text { Rotation } \\
\text { angle } \\
\text { [rad] }\end{array}$ & $\begin{array}{l}\text { Screw } \\
\text { pitch } \\
{[\mathrm{m}]}\end{array}$ & \\
\hline \multirow{3}{*}{0} & S1 & [100] & {$\left[\begin{array}{lll}0 & 0 & 0\end{array}\right]$} & 1 & 0 & \multirow{3}{*}{$3 \cdot 10^{5}$} \\
\hline & S2 & [001] & {$\left[\begin{array}{lll}0 & 0 & 0\end{array}\right]$} & 1 & 0 & \\
\hline & S3 & {$\left[\begin{array}{lll}0 & 1 & 0\end{array}\right]$} & {$\left[\begin{array}{llll}0.6799 & 0 & -0.5688\end{array}\right]$} & 0 & $10^{15}$ & \\
\hline \multirow{2}{*}{0.05} & S1 & {$\left[\begin{array}{lll}1 & 0 & 0\end{array}\right]$} & {$\left[\begin{array}{lll}0 & 0.0720 & 0\end{array}\right]$} & 1 & 0.0011 & \multirow{2}{*}{87} \\
\hline & S2 & {$\left[\begin{array}{lll}0 & 0 & 1\end{array}\right]$} & {$\left[\begin{array}{lll}0 & -0.0220 & 0\end{array}\right]$} & 1 & -0.0011 & \\
\hline \multirow{2}{*}{0.1} & S1 & {$\left[\begin{array}{lll}1 & 0 & 0\end{array}\right]$} & {$\left[\begin{array}{llll}0 & 0.1439 & 0\end{array}\right]$} & 1 & 0.0045 & \multirow{2}{*}{85} \\
\hline & S2 & {$\left[\begin{array}{lll}0 & 0 & 1\end{array}\right]$} & {$\left[\begin{array}{lll}0 & -0.0439 & 0\end{array}\right]$} & 1 & -0.0045 & \\
\hline
\end{tabular}

position when $e_{y}$ is close to zero (Tab. 2). These two degrees of freedom always occur in this coupler, allowing for changes in the coupler shaft inclination angle. The third degree of freedom appears when $e_{y}$ approaches zero (the platforms are coplanar), giving an additional, admissible linear displacements ( $\mathrm{S} 3$, the screw pitch tends to infinity) along the shaft axis (y-axis). The Jacobian matrix (Eq. 10) of the single coupler for coplanar configuration yields:

$$
\boldsymbol{J}_{4 \times 6}=\left(\begin{array}{cccc}
-0.7071 & 0.7071 & 0.7071 & -0.7071 \\
-0.7071 & -0.7071 & 0.7071 & 0.7071 \\
0 & 0 & 0 & 0 \\
0 & 0 & 0 & 0 \\
0 & 0 & 0 & 0 \\
-0.8829 & 0.8829 & -0.8829 & 0.8829
\end{array}\right) .
$$


In order to prove the existence of an additional singular position of the coupler when the platforms are coplanar, condition number (12) of the mechanism Jacobian matrix was evaluated, and given in Tab. 2. When $e_{y}$ approaches zero, the condition number of matrix (15) tends to infinity and its rank reduces to 3 . These features confirm what was stated above.

\subsection{Single coupler quality indices}

In order to analyze the coupler characteristics, it is assumed that the input shaft is rotating a full angle with constant angular velocity, what gives constant increments of the shaft angle $\left(\varphi_{a}\right)$ in time. Inclination $\left(\alpha_{b}\right)$ and axial shift $\left(\mathrm{e}_{y}\right)$ of the output shaft are changed for the analysis.

The following criteria are used for quality evaluation of the coupler system during its operation:

(i) extreme values (the smaller, the better) of difference between rotation angles of input and output coupler axles, which are responsible for the coupler homokineticity, and it is defined as:

$$
c_{1}=\max \left(\varphi_{a}-\varphi_{b}\right) \quad[\mathrm{rad}]
$$

(ii) deviation (the smaller, the better) of the $\mathrm{B}$ platform center from the input shaft rotation axis, what can be attributed to the mechanism (static) balancing problem, or demanded space in hollows, and it is defined as:

$$
c_{2}=\max \left(x_{b}\right)-\min \left(x_{b}\right)[-] \quad(* \text { for nondimensional model })
$$

(iii) maximal value of the angle $\beta_{1}$ (the smaller, the better) between the coupler link and the platform, measured in the platform plane (Fig. 2c), changes of this angle determine dimensions of the elastomeric bushings in the actual mechanism, and it is defined as:

$$
c_{3}=\max \left(\beta_{1}\right)[\mathrm{rad}]
$$

(iv) maximal value of the angle $\beta_{2}$ (the smaller, the better)between the coupler link and the platform, measured in the direction normal to the platform plane (Fig. 3c), changes of this angle determine dimensions of the elastomeric bushings in the actual mechanism, and it is defined as:

$$
c_{4}=\max \left(\beta_{2}\right)[\mathrm{rad}]
$$

\subsection{Single coupler characteristics}

The coupler homokineticity (criterion $c_{1}$ in Eq. 16) is evaluated on the basis of fluctuation between input $\left(\varphi_{a}\right)$ and output $\left(\varphi_{b}\right)$ shafts angles, what 
is presented in Fig. 6 for the coupler with original proportions $(\gamma=0.297$ $\mathrm{rad})$. The difference varies in a sinusoidal fashion with period equal to the full angle, amplitude proportional to the output shaft inclination angle ( $\alpha_{b}=$ $0.0175,0.035,0.0525 \mathrm{rad}$ ) and mean value equal to $1.57 \mathrm{rad}$ (initial angle between the reference systems of A and B platforms, Fig. 3a).

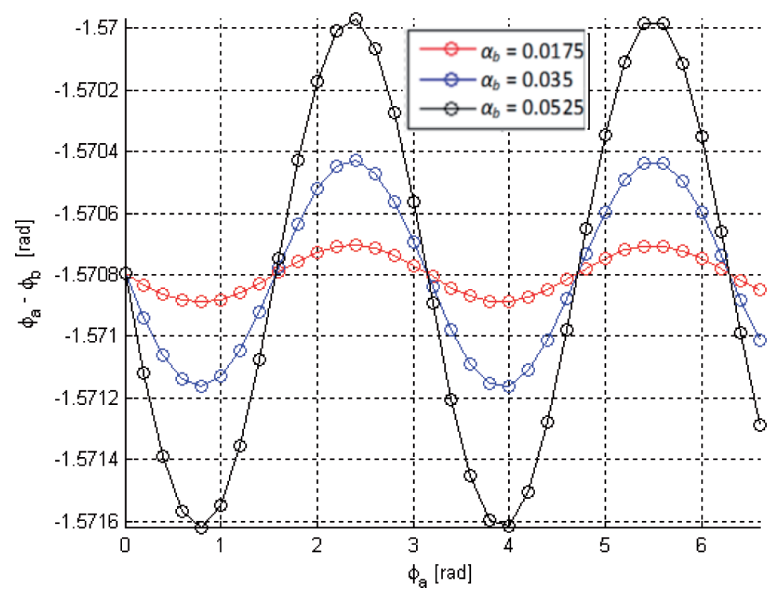

Fig. 6. Residual angle between platforms: A and B of the coupler $(\gamma=0.297 \mathrm{rad})$ as a function of the input shaft angle $\left(\varphi_{a}\right)$, when the output shaft is inclined $\left(\alpha_{b}=0.0175,0.035,0.0525 \mathrm{rad}\right)$

The coupler balancing or demanded space for the hollow (criterion $c_{2}$ in Eq. 17) is evaluated on the basis of a trajectory of platform-B center in $x z$-plane during the full rotation, Fig. 7. The point $O_{b}$ realizes a closed path with a circular fashion. The circle diameter is proportional to the output b-shaft inclination angle $\left(\alpha_{b}=0.0175,0.035,0.0525 \mathrm{rad}\right)$.

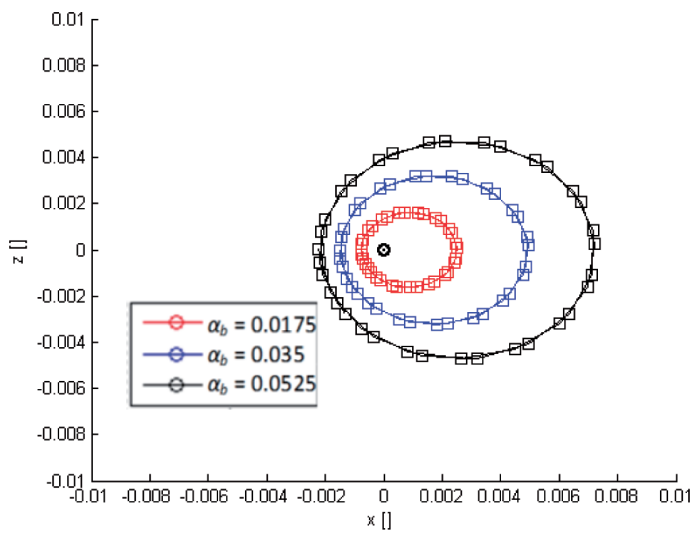

Fig. 7. Trajectory of plaftorm-B center in $x z$-plane during a full rotation of the coupler $(\gamma=0.297 \mathrm{rad})$ with output shaft inclined $\left(\alpha_{b}=0.0175,0.035,0.0525 \mathrm{rad}\right)$ 
MICHAL MANIOWSKI, TOMASZ CZAUDERNA
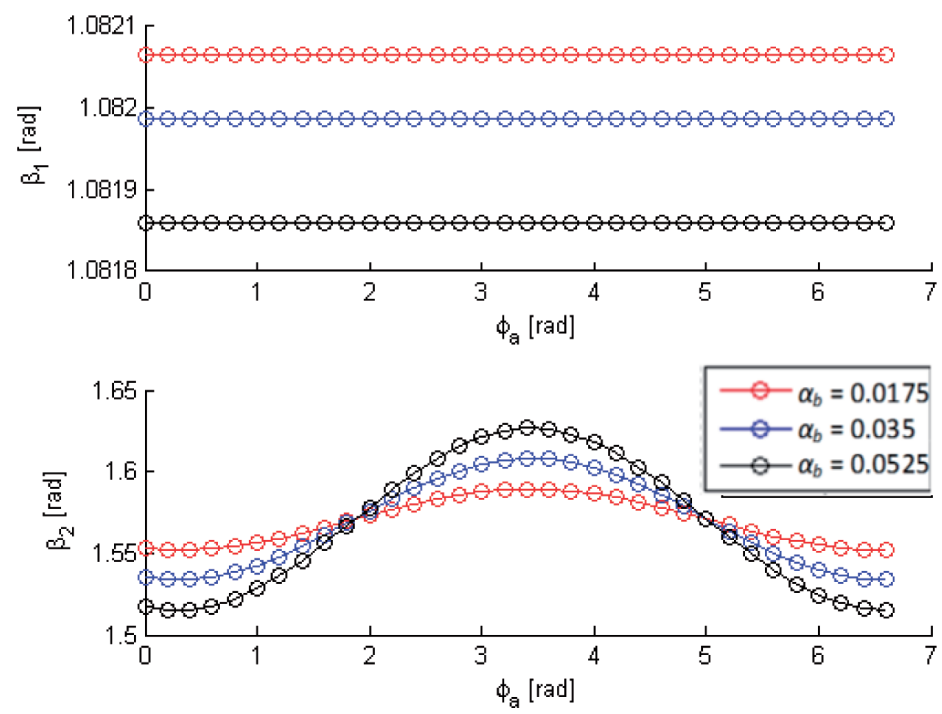

Fig. 8. Angles $\left(\beta_{1}\right.$ and $\left.\beta_{2}\right)$ between the platform and link as a function of the input shaft angle $\left(\varphi_{a}\right)$ of the coupler $(\gamma=0.297 \mathrm{rad})$ with output shaft inclined

$$
\left(\alpha_{b}=0.0175,0.035,0.0525 \mathrm{rad}\right)
$$

Changes in the angles $\beta_{1}$ and $\beta_{2}$ (Fig. 3c) were also determined for a comprehend selection of the elastomeric bushings dimensions in the actual coupler mechanism (Fig. 2). The angle $\beta_{1}$ virtually does not change (Fig. 8 above) during revolutions of the clutch. The second angle $\beta_{2}$ varies (Fig. 8 bottom) in a cosine fashion with a period equal ( 2 full rotations) and an amplitude proportional to the output b-shaft inclination angle $\left(\alpha_{b}=0.0175\right.$, $0.035,0.0525 \mathrm{rad})$.

The described above criteria $\left(c_{1}, c_{2}, c_{3}\right.$ and $\left.c_{4}\right)$ for evaluation of the single 4-link coupler quality are together presented in Fig. 9 as functions of the shaft inclination angle $\alpha_{b}$ and the design parameters $\gamma$ and $e_{y}$.

The coupler homokineticity (criterion $c_{1}$, Fig. 9) depends in a parabolic fashion on the shaft inclination angle $\alpha_{b}$, what confirms the results given in [7]. This criterion can be improved (lowered) when the coupler changes its proportions from $\gamma=0.391 \mathrm{rad}$ (the platforms are more wide and links are shorter) to $\gamma=0.11 \mathrm{rad}$ (the platforms are more slim and links are longer). Criterion $c_{1}$ is virtually not influenced by the platform shift $\left(e_{y}\right)$.

Criterion $c_{2}$ (Fig. 9) deteriorates (obtains higher value) proportionally to the increase of: the shaft inclination angle $\left(\alpha_{b}\right)$, the coupler proportion $\operatorname{parameter}(\gamma)$ and the platform shift $\left(e_{y}\right)$.

Comparing criteria $c_{3}$ and $c_{4}$ (Fig. 9), one can notice that the last one (related to $\beta_{2}$ ) achieves 10 times greater values than the first (related to $\beta_{1}$ ). Criterion $c_{4}$ deteriorates (obtains higher value) proportionally to the increase 

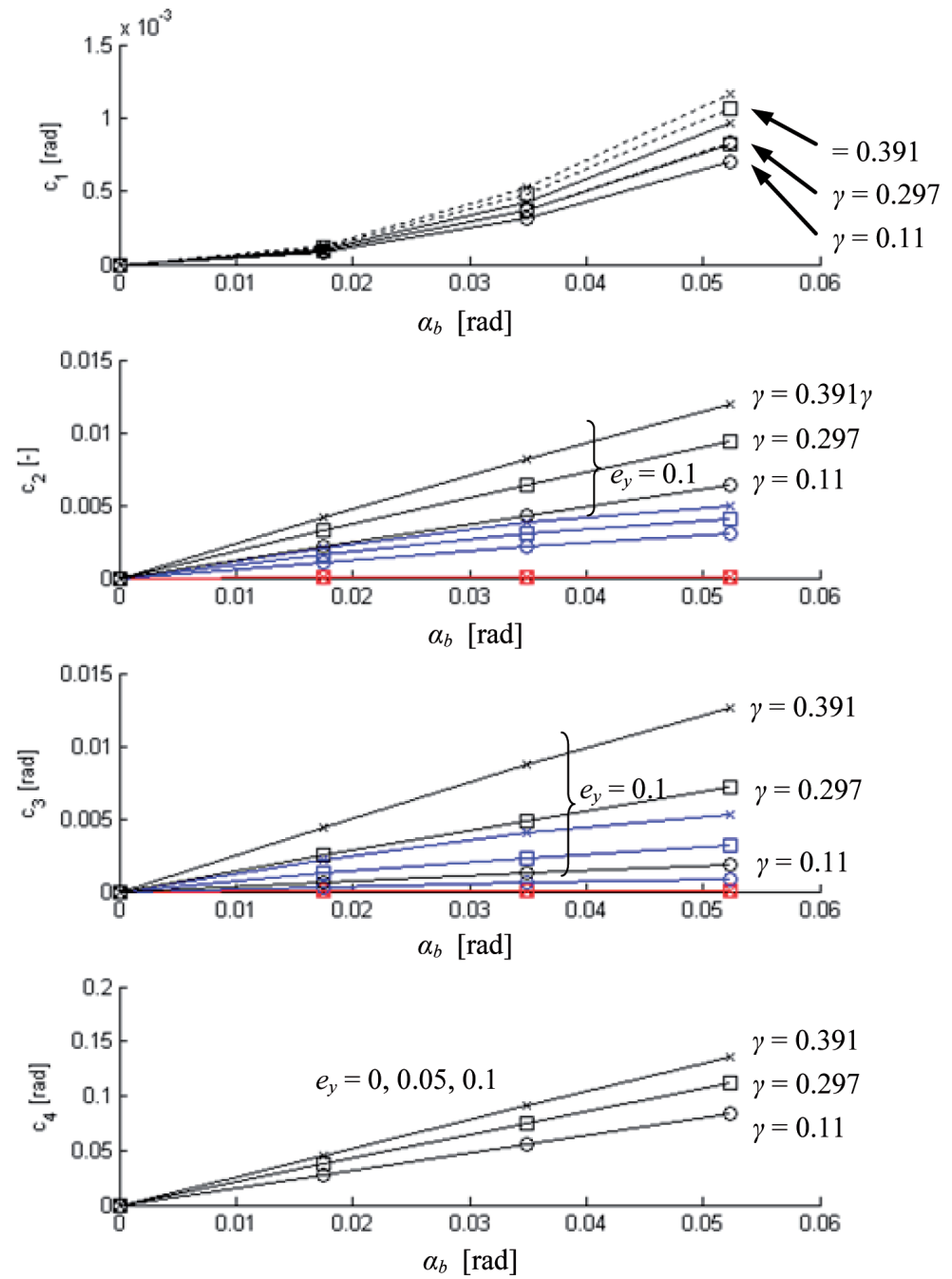

Fig. 9. Criteria $c_{1}, c_{2}, c_{3}$ and $c_{4}$ for evaluation of the single 4-link coupler quality as functions of shaft inclination angle $\alpha_{b}$ and design parameters $\gamma$ and $e_{y}$

of: the shaft inclination angle $\left(\alpha_{b}\right)$, the coupler proportion parameter $(\gamma)$. The platform shift $\left(e_{y}\right)$ is insignificant here.

\section{Analysis of double 4-link coupler}

\subsection{Simulations plan}

The following kinematic analyses include the system of double 4-link coupler, which is typically used in actual powertrain systems. Serial connection of the 4-link couplers can give its characteristics closer to an ideal 
coupler. Geometric model of the double coupler in an initial (upright) pose is presented in Fig. 4. Input shaft is noted with letter ' $a$ ', intermittent shaft with ' $b$ ' and ' $c$ ' is for the output shaft.

It is still assumed that the input shaft-a is rotating a full angle with constant angular velocity, what gives constant increments of the shaft angle $\left(\varphi_{a}\right)$ in time. The following kinematic parameters are changed for the analysis:

- lateral position of the output c-shaft (described by $z_{c}$ component),

- $\varphi_{b c}$ angle (0 or $1.57 \mathrm{rad}$ ) between platforms-B and $\mathrm{C}$ of shaft-b,

- $l_{b}$ length of the $b$-shaft.

\subsection{Double coupler quality indices}

In order to evaluate quality of the double coupler system during its operation, an additional criterion $\left(c_{5}\right)$ is defined below with respect to the case of the single coupler system (presented in chapter 3.3):

$$
c_{5}=\max \left(\varphi_{a}-\varphi_{c}\right) \quad[\mathrm{rad}]
$$

The difference between rotation angles (Eq. 20) of input (a) and output (c) coupler shafts is responsible for the coupler homokineticity, therefore, the smaller means the better.

\subsection{Double coupler characteristics}

Determined criterion $c_{5}$ as function of lateral displacement of the output shaft (c) is presented in Fig. 10. Considering length $\left(l_{b}\right)$ of the coupler middle shaft, the longer means the better (but needs more space). The design case of the coupler with the right angle $\left(\varphi_{b c}=1.57 \mathrm{rad}\right)$ between the platforms on b-shaft gives variation of the coupler ratio. However, this solution is not used in the actual mechanism. Simulation results confirm a possibility of the coupler full homokineticity when $\varphi_{b c}=0 \mathrm{rad}$, independently of the output shaft lateral position.

\section{Conclusions and future works}

In the paper, a double 4-link coupler system, used in actual powertrain of low-floor tram (NGT6-Kr), is considered. In the first part, taking advantage of the formulated spatial, kinematic model the mobility and singularity analysis of the coupler mechanism with kinematic constraints was performed. Local free motions of the mechanism in singular configuration were determined on the basis of mechanism Jacobian matrix. Jacobian rank gives information about the mechanism degrees of mobility. Jacobian condition number was used to estimate singular poses of the mechanism. 


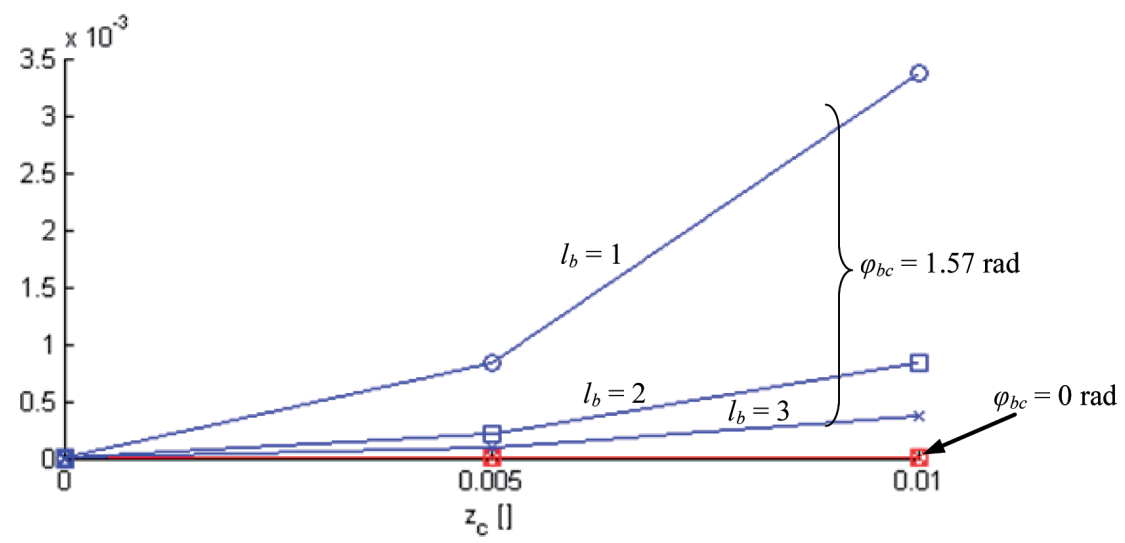

Fig. 10. Criterion $c_{5}$ for evaluation of the double 4-link coupler quality as function of: $\left(z_{c}\right)$ lateral shift of the output c-shaft, $\left(\varphi_{b c}\right)$ angle between platforms of b-shaft, and $\left(l_{b}\right)$ length of b-shaft

In the second part, kinematic characteristics of the single and double coupler system were analyzed for gross angular and linear axle displacements, taking the advantage of the fully nonlinear model. The coupler system was evaluated based on criteria describing homokinetics, balancing and clearance demands, and angular displacements in the real link's bushings. The simulation results confirmed that a single coupler mechanism with kinematic constraints only (spherical joints in the links) can permit angular change of the drive train axles up to $\pm 4 \mathrm{deg}$. Double system of the couplers increases this range two times and enables side-to-side displacement of the axles. Additional geometric parameters, like intermittent shaft length, angle between middle platforms, were changed here in order to check their significance on the coupler quality. The obtained results confirmed that the actual mechanism is designed with taking into account compromise between the best performance, minimum space requirements, the highest strength and durability.

Including compliant bushings in the coupler links enables farther increase of inclinations and relative displacements of the drive train axles [1]. Therefore, the following future works are planned:

- elastokinematic analysis regarding elastic deflections of elastomeric bushings installed in coupler links;

- preparation and realization of the real coupler measurements, installed in an indoor test rig;

- model verification based on of the measurement results;

- propositions for further design improvements. 


\section{REFERENCES}

[1] Czauderna T., Maniowski M.: Analiza podatności sprzęgła 4-cięgłowego stosowanego w niskopodłogowych tramwajach (Stiffness analysis of 4-link coupler used in lowfloortrams). Zeszyt Naukowo-Techniczny, nr 3 (102) s. 61-71, 2013 (in Polish).

[2] Czauderna T.: Analiza przestrzennego układu dwóch sprzęgieł czterocięgłowych stosowanych w niskopodłogowych tramwajach (Analysis of double 4-link couplers system used in lowfloortrams). Zeszyt Naukowo-Techniczny, nr 3 (99) s. 103-117, 2012 (in Polish).

[3] Frączek J., Wojtyra M.: Kinematyka układów wieloczłonowych (Kinematics of multibody systems), WNT Warsaw, 2009 (in Polish).

[4] Gogu G.: Mobility of mechanisms: a critical review, Mechanism and Machine Theory, Vol. 40, Issue 9, s. 1068-1097, 2005.

[5] Grzyb A., Kuczek T.: Symulacja komputerowa kinematyki sprzęgła odsuwnego typu Oerlikon z uwzględnieniem podatności przegubów (Kinematic analysis of Oerlikon coupler including joint compliance). XV Warsztaty Naukowe Polskiego Towarzystwa Symulacji Komputerowej (Scientific Workshop of Polish Computer Simulation Sociate) 25-09-2008, Zakopane, 2008 (in Polish).

[6] http://www.mathworks.com

[7] Madej J.: Mechanika transmisji momentu trakcyjnego (Mechanics of thrust torque transmition). Oficyna Wydawnicza Politechniki Warszawskiej) Warsaw 2000 (in Polish).

[8] Tsai L.: Robot Analysis: The Mechanics of Serial and Parallel Manipulators. Willey 1999.

[9] Dokumentacja techniczna - Miejskie Przedsiębiorstwo Komunikacyjne SA., Kraków (Technical Data, Cracow City Transport), 2012 (in Polish).

[10] Morecki A., Knapczyk J., Kędzior K.: Teoria mechanizmów i manipulatorów (Theory of mechanism and manipulators), WNT Warsaw, 2002 (in Polish).

[11] Osiecki J.: Equations of vibrations and analysis of the dynamics loadings of a drive system with Alsthom-type couplings, Nonlin. Vibr. Problems, 10, s. 225-243, 1969.

[12] Osiecki J.: Drgania układów mechanicznych z wałami przegubowymi zawierającymi sprzęgła cięgłowe (Vibrations of mechanical systems with joint shafts including link couplers). The Archive of Mechanical Engineering, Vol. 17, 1970 (in Polish).

[13] Romaniszyn Z.: Podwozia wózkowe pojazdów szynowych (Chassis bogies of rail vehicles). Wydawnictwo Politechniki Krakowskiej, Cracow 2005 (in Polish).

[14] Życzkowski M., Romaniszyn Z.: Optymalizacja kinematyczna mechanizmu cięgłowego typu Alsthom (Kinematic optimisation of Alsthom link mechanism), Archive of Mechanical Engineering, Vol. XVI, Cracow 1969 (in Polish).

\section{Przestrzenna analiza kinematyczna układu podwójnego sprzęgła 4-cięgłowego wykorzystywanego $\mathrm{w}$ tramwajach niskopodłogowych}

Streszczenie

W pracy przestawiono charakterystyki kinematyczne układu napędowego z podwójnym sprzęgłem 4-cięgłowym, wykorzystywanym w tramwajach nisko-podłogowych (NGT6-Kr). Przestrzenny model kinematyczny sprzęgła został sformułowany zakładając idealne przeguby i sztywne ogniwa.

Równania więzów mechanizmu rozwiązano iteracyjnie, a następnie zróżniczkowano w celu wyznaczenia macierzy jakobianowej mechanizmu. Macierz tą wykorzystano do analizy ruchliwości 
i osobliwości mechanizmu sprzęgła. Charakterystyki kinematyczne układu z pojedynczym i podwójnym sprzęgłem analizowano w zakresie dużych kątowych i liniowych przemieszczeń wałów układu napędowego. Układ sprzęgłowy oceniano w oparciu o następujące kryteria: homokinetyczność, wyrównoważenie, ograniczenie przestrzeni roboczej oraz dopuszczalne przemieszczenie w przegubach mechanizmu. Analiza parametryczna dotyczyła takich zmiennych konstrukcyjnych, jak: proporcje sprzęgła, przesunięcie i orientacja platform sprzęgieł, czy długość wału pośredniego. 